\title{
FACTORS INFLUENCING NONTARGET BIRD OCCUPANCY OF RESTORED WETLANDS IN CALIFORNIA'S CENTRAL VALLEY
}

\author{
SHARON N. KAHARA, Humboldt State University, Department of Wildlife, 1 Harpst \\ St., Arcata, California 95521; Sharon.Kahara@humboldt.edu \\ WALTER G. DUFFY, U. S. Geological Survey, California Cooperative Fish and Wild- \\ life Research Unit, Humboldt State University, Arcata, California 95521
}

RYAN DiGAUDIO, Point Blue Conservation Science, 3820 Cypress Drive \#11, Petaluma, California 94954

ROSEMARY RECORDS, Colorado State University, Department of Watershed Science and Department of Civil and Environmental Engineering, Fort Collins, Colorado 80523

ABSTRACT: Intensively managed restored wetlands and flooded croplands of California's Central Valley support millions of wintering waterbirds. While the benefits to wintering waterfowl are well documented, the effect of intensive management on birds at other times of the year is less clear. Practices such as drainage, mowing, disking and burning may be a nuisance to these nontarget birds at best or life threatening at worst. Alternatively, irrigation over the summer may create habitat that might otherwise be lacking in the dry season. Our objective was to assess the influence of management, adjacent land use, and habitat characteristics on the richness, diversity, and occupancy of birds other than waterfowl in the spring and summer. We conducted 640 bird surveys on restored wetlands managed at varying levels in 2008 (4 April-30 July) and 2009 (19 April-16 July) and used likelihood-based modeling to evaluate occupancy and the relative importance of intensity of management and various environmental factors. Management was not the most important predictor of the richness, diversity, or occupancy of nontarget birds in the summer; rather, variables such as wetland size, vegetation composition, and landscape characteristics were more important for most bird guilds. Contrary to the commonly held view that restored wetlands in California's Central Valley support only wintering waterfowl, they also support a diverse avifauna year round regardless of how they are managed. Bird occupancy and diversity in restored wetlands may be enhanced by creating and maintaining large, complex mosaics of vegetation.

Each year California's Central Valley hosts the majority of the Pacific Flyway's wintering waterfowl (Gilmer et al. 1982). Restored wetlands provide critical food and habitat for winter visitors, and there is broad support for programs and initiatives geared toward increasing the extent of wetlands in winter (CVJV 2006). Far less emphasis is placed on the role restored wetlands play in supporting summer breeders, migrants, and year-round residents.

Greater than $95 \%$ of all depressional wetlands and $98 \%$ of riparian wetlands in California were destroyed between 1800 and 1980 (Dahl 1990, CVJV 2006, Garone 2011, Duffy et al. 2016). The passage of the Swamplands Act in 1850 and subsequent revisions led to extensive alterations to natural hydrology through the creation of reservoirs and channelization of the Central Valley's main rivers. Restoration has been intended to replace the thousands of acres of wetland lost to agriculture and human settlement. Most managed restored wetlands target wintering waterfowl and therefore receive most of their water in the fall and winter. Historically, however, much of the 
Central Valley flooded in early spring and summer following peak flows in the Sacramento and San Joaquin rivers (Katibah 1984). The effects of this shift in the timing of flooding on wildlife occupying these wetlands in spring and summer are often overlooked. Greater scrutiny of the factors affecting spring and summer birds may help enhance biodiversity and expand their ecosystem service.

State legislation governing water appropriation and individual landowners' water rights constrain wetland management by limiting access to surface water. As a result, the Central Valley's restored wetlands are managed at widely different levels, from none to intensive (Duffy et al. 2011). Intensive management usually involves a series of hydrological manipulations including a drawdown of the water level in spring and irrigation in summer so seed-producing plants germinate in high density. This is followed by artificial flooding in the fall to coincide with the arrival of wintering waterfowl, a strategy often referred to as "moist-soil management" (Fredrickson and Taylor 1982). Moist-soil management also includes disking, mowing, burning, and herbicide application to maintain a desired composition of vegetation or to eliminate invasive plants and mosquitoes (Fredrickson and Taylor 1982, CVJV 2006). These activities typically take place between March and August when they may disturb breeding birds. Similar agricultural practices have been faulted for birds' avoiding a site and population declines (e.g., Beedy and Hamilton 1999, Zuckerberg and Vickery 2006). Alternatively, irrigation over the dry summer may attract opportunistic birds to managed wetlands.

Though managed wetlands support a wide variety of birds in the spring and summer (Kahara et al. 2012), it is unclear whether bird occupancy in those seasons is driven primarily by moist-soil management or other factors. Other studies suggest that characteristics of the site (e.g., Webb et al. 2010) and adjacent landscape (Sterling and Buttner 2011, Fleskes et al. 2012) play an important role, depending on the species. Our primary objective was to assess the relative importance of intensity of management, habitat at the site, and characteristics of the surrounding landscape in determining these wetlands' occupancy by and diversity of birds from April to July.

\section{STUDY AREA}

The Central Valley, about $650 \mathrm{~km}$ long and $120 \mathrm{~km}$ wide, covers 108,800 $\mathrm{km}^{2}$ (Schoenherr 1992), 26\% of the total area of California. It may be subdivided into the Sacramento River sub-basin in the north and San Joaquin and Tulare sub-basins in the south (Figure 1). Its topography is relatively flat, elevations ranging from $120 \mathrm{~m}$ in the north and south to below sea level in the Sacramento-San Joaquin delta (Schoenherr 1992). Over 90\% of precipitation falls from November to May. Air temperatures vary little through the valley; average July highs approach $38^{\circ} \mathrm{C}$ at both Bakersfield in the south and Redding in the north, while average December lows at Bakersfield (2.9 $\left.{ }^{\circ} \mathrm{C}\right)$ are only slightly warmer than at Redding $\left(2.7^{\circ} \mathrm{C}\right)$. Precipitation decreases from north (average $90 \mathrm{~cm} /$ year) to south (average $12 \mathrm{~cm} /$ year) and from east to west, because of the rain shadow of the Coast Ranges (Carter and Resh 2005). We used the three Central Valley sub-basins to categorize our study sites along the gradient of precipitation. 


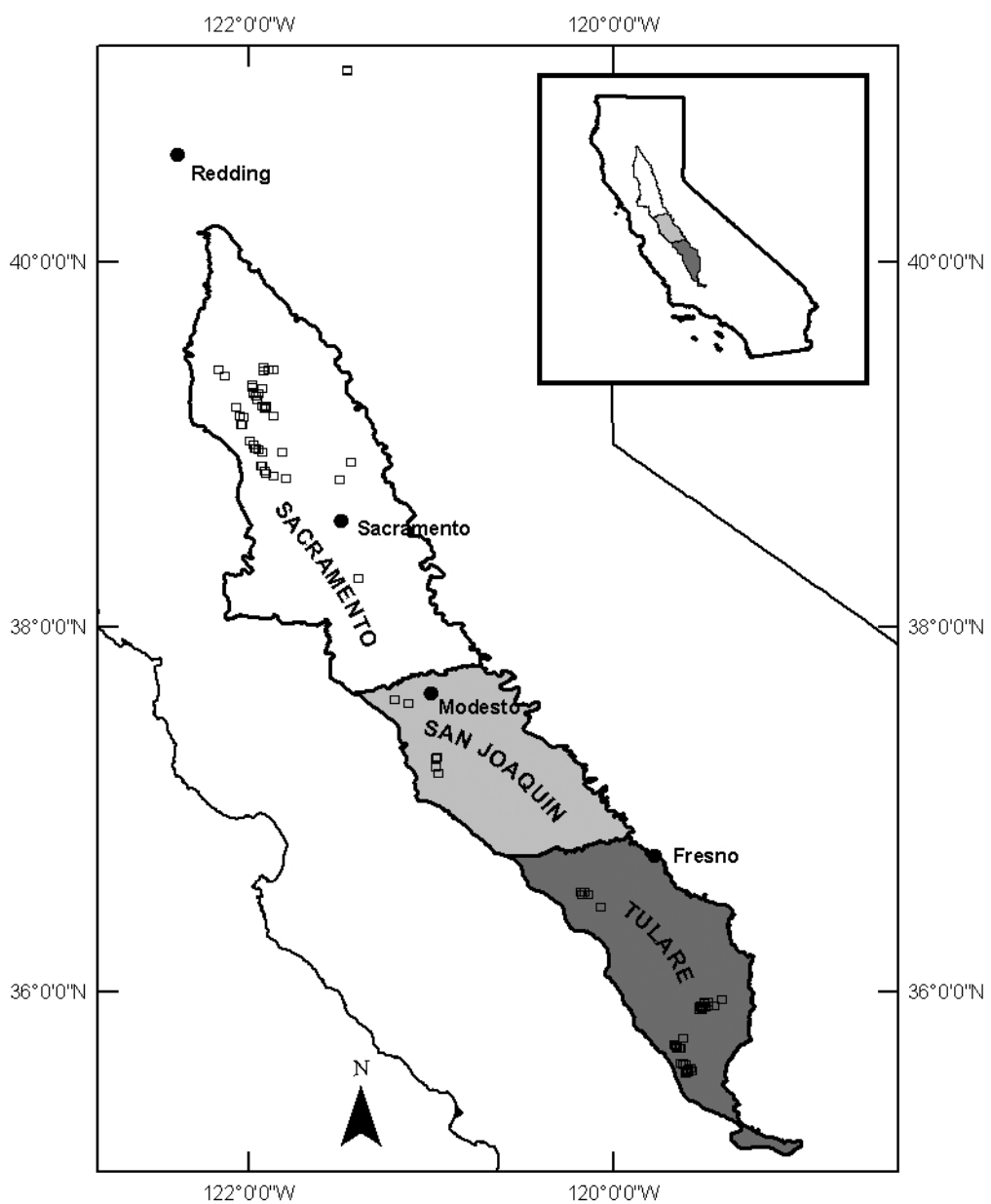

Figure 1. Location of 2008 and 2009 sampling sites (squares) in California's Central Valley, in the context of three major sub-basins, Sacramento (white); San Joaquin (light gray), and Tulare (dark gray).

Most of our study sites were wetlands restored under the Wetlands Reserve Program (WRP), a U.S. Department of Agriculture (USDA) conservation initiative established under the Food Security Act of 1985. The WRP gave private landowners the opportunity to restore, protect, and enhance wetlands on their property through a cost-share agreement with the USDA and applied only to converted former wetlands. The Agricultural Act of 2014 replaced the WRP with the Agricultural Conservation Easement Program (ACEP); however, WRP easements established prior to the enactment of ACEP remain valid for the duration of their contracts. 
WRP easements are often subdivided into smaller manageable areas or "units" that are typically between 10 and 50 ha in size. Wetland units comprise a basin surrounded on all sides by levees 1-2 meters high to hold water. Troughs, islands, and sloughs are common design features for varying the topography and water depths within the basin while allowing water to be conveyed from inlets to outlets. When flooded, wetland units with varied topography promote the germination of a diverse assemblage of plants depending on their tolerance for duration and depth of flooding (van der Valk and Davis 1978, Fredrickson and Taylor 1982).

\section{METHODS}

From 10 April to 30 July 2008, we surveyed 60 units in 26 wetlands restored under the WRP and one unit in Kern National Wildlife Refuge. From 19 April to 16 July 2009, we surveyed 11 units in 11 WRP wetlands. Three sites were surveyed in both years.

For this study, we ranked wetlands by three levels of intensity of management according to assessments by biologists with the Natural Resource Conservation Service and interviews with land owners. Management at the highest level ("intensive") entailed a combination of moist-soil techniques including hydrological and mechanical manipulation every year since restoration. Wetlands managed at the intermediate level received some or all techniques of moist-soil management in at least $50 \%$ of the years since restoration. Unmanaged wetlands had never had any moist-soil management techniques applied to them since restoration. We also categorized wetlands by time since restoration, as relatively young ( 5 years or less since restoration at time of sampling) or relatively old ( $>5$ years since restoration at time of sampling). Most wetlands ranged in age from 0 (restored within 12 months of our surveys) to 12 years.

\section{Habitat Surveys}

We distinguished uplands from wetlands by their preponderance of flood-intolerant plants and grasses. We subdivided wetlands, dominated by flood-tolerant plants, into four approximately circular concentric zones around the lowest elevation in the unit and defined by plant species with similar tolerance for depth and duration of flooding: (1) moist soil, (2) shallow emergent vegetation, (3) deep emergent vegetation, and (4) open water. We then defined four transects per unit, beginning each at the outer edge in each of the four cardinal directions around the unit and continuing them along a depth gradient toward the center of the wetland, until we encountered open water or until the vegetation became uniform. In the latter case, we limited transects to $100 \mathrm{~m}$, and distances between transects were not fixed. We then measured the radius from the center of the lowest zone to the outer perimeter of each zone and estimated the area of each zone as $\pi\left(R_{1}^{2}-R_{2}^{2}\right)$, where $R_{1}$ and $R_{2}$ are the zone's outer and inner radii. From these areas, we calculated the proportion each zone represented of the unit's entire area. We used the number of zones in each wetland unit as an indicator of its habitat complexity. 
We estimated land use within a $10-\mathrm{km}$ radius of each wetland unit $\left(\mathrm{m}^{2}\right)$, using the 2008 and 2009 cropland data layers for California (http://www. nass.usda.gov/research/Cropland/SARS1a.htm) with ArcMap 9.3 (ESRI, Redlands CA). Existing land uses were reclassified under 12 categories of agricultural and non-agricultural land use. We analyzed rice, corn, and other grains separately, as waterfowl forage on them more than on other crops (Ackerman et al. 2006, CVJV 2006).

\section{Bird Surveys}

By area searches (Ralph et al. 1993), we surveyed all birds in the selected wetlands from 4 to 13 times (mean 8.5) approximately once every 3 weeks. Experienced observers equipped with spotting scopes began all surveys within half an hour after local sunrise. We omitted birds flying over, unless they were foraging aerially, and did not broadcast recorded calls, so numbers of secretive marsh birds such as rails were underestimated.

\section{Data Analysis}

We grouped species by 11 guilds defined by shared foraging behaviors and similar environmental requirements (Hickey et al. 2008). Then we compared the richness and diversity of species by intensity of management, sub-basin, and time since restoration according to the Shannon-Wiener index, which is also a measure of entropy (uncertainty) that reflects differences in proportional abundances of birds. Smaller values indicate wider variation in proportional abundance of species within the community and dominance by one or a few species. For comparisons of the number of vegetation zones, water depth, and proportion of each vegetation zone by intensity of management we used a Kruskal-Wallis one-way analysis of variance.

\section{Bird-Occupancy Models}

We used the program Presence (version 3.1; United States Geological Survey, Patuxent Wildlife Research Center, Laurel, MD) to model site occupancy and distinguished between models by means of Akaike's information criterion corrected for small sample sizes $\left(\mathrm{AIC}_{\mathrm{c}}\right.$; Burnham and Anderson 2002). Program Presence estimates the likelihood of detection from patterns of detection and nondetection over multiple visits to the site (MacKenzie et al. 2002). We selected covariates a priori on the basis of our observations in the field and previous research during a period including spring migration but before fall migration (Kahara et al. 2012).

We considered a site occupied by a guild if at least one species of the guild was detected, unoccupied if no species of the guild was detected on any visit. To identify the model with the lowest value of $\mathrm{AIC}_{c}$ (reduced model), we modeled probability of occurrence as a function of each covariate both individually and in combination. If in any given model this value was greater than in the reduced model, then we eliminated that variable from further consideration. If two of the retained variables were correlated (Pearson correlation coefficient $r \geq|0.7|$ ), we eliminated the variable with the higher $\mathrm{AIC}_{c}$ value. We ranked the models by $\mathrm{AIC}_{c}$ value and report the "best" model (lowest $\mathrm{AIC}_{c}$ value). 
Table 1 Size and Time since Restoration of Restored Wetlands Surveyed in California's Central Valley, 2008 and 2009

\begin{tabular}{lcccc}
\hline \multirow{2}{*}{$\begin{array}{l}\text { Intensity of } \\
\text { management }\end{array}$} & $n$ & $\begin{array}{c}\text { Average size } \\
\text { (ha, } \pm \text { SE) }\end{array}$ & \multicolumn{2}{c}{$n$ by years since restoration } \\
\hline Unmanaged & 15 & $329(7.4)$ & 9 & $>5$ years \\
Intermediate & 31 & $334(4.9)$ & 22 & 6 \\
Intensive & 26 & $31(0.2)$ & 11 & 15 \\
\hline
\end{tabular}

\section{RESULTS}

We completed 508 bird surveys on 61 sites in 2008 and 132 surveys on 11 sites in 2009. In both years the largest number of sites was managed at the intermediate level (43\% in 2008, $45 \%$ in 2009), followed by intensively managed $(36,36)$ and unmanaged $(21,18)$. Intensively managed sites were older and smaller than intermediate and unmanaged sites (Table 1). Sites managed at different intensities differed mainly in vegetation composition. Unmanaged sites had significantly more upland vegetation (average 9.4\%) than either intermediate or intensively managed sites. Wetland vegetation covered an average of $8.1 \%$ of intensively managed sites and $11.3 \%$ of intermediate sites, more than three times that of unmanaged sites (3.4\%). Intensively managed sites had the most shallow marsh vegetation (average $6.1 \%$ ), though not much more than unmanaged sites (average 5.7\%). At all three levels of management deep marsh vegetation covered the least area, most on intermediate sites (average 0.6\%). Vegetation coverage (average $6.6 \%)$ and depth $(4.5 \mathrm{~cm})$ of water were greatest on unmanaged sites in the summer but were not significantly different.

\section{Bird Data}

Over the survey period, we recorded 174 and 112 species in 2008 and 2009 respectively (Table 2). These included 17 species currently listed as of concern in California or nationwide (Hickey et al. 2008). Most special-status birds favored older, intensively managed wetlands in the northern Central Valley (Table 3). Smaller values of the Shannon-Wiener index suggest a greater disparity in species' abundance in the Tulare sub-basin than in the other two sub-basins (Table 4). Occupancy and species diversity of upland birds were best described by the null model (including all covariates), indicating that the mean probability of use did not differ by wetland unit or could not be differentiated by the covariates we selected.

Covariates selected in the most parsimonious bird-occupancy models varied by guild (Table 5). Though management was included in some of the top ten models for wading birds, marsh birds, dabbling ducks, and aerial feeders, it was not the most important variable. Habitat complexity was the most important variable determining occupancy by wading birds, marsh birds, and shorebirds and an important variable for all wetland guilds except geese. The most important variable influencing goose occupancy was sub-basin, most geese being found in the Sacramento sub-basin. Moist 
Table 2 Principal Bird Species ${ }^{a}$ Recorded April-July 2008 and 2009 on Restored Wetlands in California's Central Valley, by Guild

\begin{tabular}{|c|c|}
\hline Guild & Species (most abundant in bold) \\
\hline Wading birds & $\begin{array}{l}\text { Black-crowned Night-Heron (Nycticorax nycticorax), Cattle Egret } \\
\text { (Bubulcus ibis), Great Blue Heron (Ardea herodias), Great Egret } \\
\text { (A. alba), Green Heron (Butorides virescens), Snowy Egret (Egretta } \\
\text { thula), White-faced Ibis (Plegadis chihi) }\end{array}$ \\
\hline Marsh birds & $\begin{array}{l}\text { American Bittern (Botaurus lentiginosus), Virginia Rail (Rallus } \\
\text { limicola), Common Gallinule (Gallinula galeata), American } \\
\text { Coot (Fulica americana), Marsh Wren (Cistothorus palustris), } \\
\text { Common Yellowthroat (Geothlypis trichas), Red-winged Blackbird } \\
\text { (Agelaius phoeniceus), Tricolored Blackbird (A. tricolor), Yellow- } \\
\text { headed Blackbird (Xanthocephalus xanthocephalus) }\end{array}$ \\
\hline Geese & $\begin{array}{l}\text { Canada Goose (Branta canadensis), Greater White-fronted Goose } \\
\text { (Anser albifrons), Snow Goose (Chen caerulescens) }\end{array}$ \\
\hline Diving birds & $\begin{array}{l}\text { Canvasback (Aythya valisineria), Redhead (A. americana), Ring- } \\
\text { necked Duck (A. collaris), Lesser Scaup (A. affinis), Ruddy Duck } \\
\text { (Oxyura jamaicensis), Pied-billed Grebe (Podilymbus podiceps), } \\
\text { Clark's Grebe (Aechmophorus clarkii), Double-crested Cormorant } \\
\text { (Phalacrocorax auritus), American White Pelican (Pelecanus } \\
\text { erythrorhynchos), Caspian Tern (Hydroprogne caspia), Forster's } \\
\text { Tern (Sterna forsteri), Belted Kingfisher (Megaceryle alcyon) }\end{array}$ \\
\hline Dabbling ducks & $\begin{array}{l}\text { Wood Duck (Aix sponsa), Gadwall (Anas strepera), American Wigeon } \\
\text { (A. americana), Mallard (A. platyrhynchos), Blue-winged Teal } \\
\text { (A. discors), Cinnamon Teal (A. cyanoptera), Northern Shoveler (A. } \\
\text { clypeata), Northern Pintail (A. acuta), Green-winged Teal (A. crecca) }\end{array}$ \\
\hline Shorebirds & $\begin{array}{l}\text { Black-necked Stilt (Himantopus mexicanus), American Avocet } \\
\text { (Recurvirostra americana), Black-bellied Plover (Pluvialis } \\
\text { squatarola), Semipalmated Plover (Charadrius semipalmatus), } \\
\text { Killdeer (C. vociferus), Spotted Sandpiper (Actitis macularius), } \\
\text { Greater Yellowlegs (Tringa melanoleuca), Lesser Yellowlegs (T. } \\
\text { flavipes), Whimbrel (Numenius phaeopus), Long-billed Curlew } \\
\text { (N. americanus), Least Sandpiper (Calidris minutilla), Western } \\
\text { Sandpiper (C. mauri), Long-billed Dowitcher (Limnodromus } \\
\text { scolopaceus), Wilson's Snipe (Gallinago delicata), Wilson's } \\
\text { Phalarope (Phalaropus tricolor), Red-necked Phalarope (P. lobatus) }\end{array}$ \\
\hline Aerial feeders & $\begin{array}{l}\text { Western Wood-Pewee (Contopus sordidulus), Ash-throated Flycatcher } \\
\text { (Myiarchus cinerascens), Barn Swallow (Hirundo rustica), } \\
\text { Cliff Swallow (Petrochelidon pyrrhonota), Northern Rough- } \\
\text { winged Swallow (Stelgidopteryx serripennis), Tree Swallow } \\
\text { (Tachycineta bicolor), Western Kingbird (Tyrannus verticalis) }\end{array}$ \\
\hline Raptors & $\begin{array}{l}\text { White-tailed Kite (Elanus leucurus), Northern Harrier (Circus } \\
\text { cyaneus), Swainson's Hawk (Buteo swainsoni), Red-tailed Hawk (B. } \\
\text { jamaicensis), American Kestrel (Falco sparverius), Great Horned } \\
\text { Owl (Bubo virginianus), Burrowing Owl (Athene cunicularia), } \\
\text { Loggerhead Shrike (Lanius ludovicianus) }\end{array}$ \\
\hline Gulls & Ring-billed Gull (Larus delawarensis) \\
\hline
\end{tabular}


Table 2 (continued)

\begin{tabular}{l} 
Species (most abundant in bold) \\
\hline Upland birds \\
California Quail (Callipepla californica), Wild Turkey (Meleagris \\
gallopavo), Ring-necked Pheasant (Phasianus colchicus), Turkey \\
Vulture (Cathartes aura), Mourning Dove (Zenaida macroura), \\
Anna's Hummingbird (Calypte anna), Black-chinned Hummingbird \\
(Archilochus alexandri), Nuttall's Woodpecker (Picoides nuttallii), \\
Downy Woodpecker (P. pubescens), Black Phoebe (Sayornis \\
nigricans), Warbling Vireo (Vireo gilvus), Western Scrub-Jay \\
(Aphelocoma californica), Yellow-billed Magpie (Pica nuttalli), \\
American Crow (Corvus brachyrhynchos), Common Raven \\
(C. corax), Cedar Waxwing (Bombycilla cedrorum), Western \\
Bluebird (Sialia mexicana), American Robin (Turdus migratorius), \\
European Starling (Sturnus vulgaris), Northern Mockingbird \\
(Mimus polyglottos), White-breasted Nuthatch (Sitta carolinensis), \\
Bewick's Wren (Thryomanes bewickii), House Wren (Troglodytes \\
aedon), Oak Titmouse (Baeolophus inornatus), Bushtit (Psaltriparus \\
minimus), Wrentit (Chamaea fasciata), Horned Lark (Eremophila \\
alpestris), American Pipit (Anthus rubescens), Song Sparrow \\
(Melospiza melodia), White-crowned Sparrow (Zonotrichia \\
leucophrys), Savannah Sparrow (Passerculus sandwichensis), \\
Grasshopper Sparrow (Ammodramus savannarum), Lark Sparrow \\
(Chondestes grammacus), Spotted Towhee (Pipilo maculatus), \\
California Towhee (Melozone crissalis), Orange-crowned Warbler \\
(Oreothlypis celata), Yellow Warbler (Setophaga petechia), \\
Wilson's Warbler (Cardellina pusilla), Western Tanager (Piranga \\
ludoviciana), Black-headed Grosbeak (Pheucticus melanocephalus), \\
Blue Grosbeak (Passerina caerulea), Lazuli Bunting (P. amoena), \\
Bullock's Oriole (Icterus bullockii), Western Meadowlark (Sturnella \\
neglecta), Great-tailed Grackle (Quiscalus mexicanus), Brewer's \\
Blackbird (Euphagus cyanocephalus), Brown-headed Cowbird \\
(Molothrus ater), American Goldfinch (Spinus tristis), Lesser \\
Goldfinch (S. psaltria), House Finch (Haemorhous mexicanus), \\
House Sparrow (Passer domesticus) \\
\hline
\end{tabular}

${ }^{a}$ Occurring at three or more sites, with five or more sightings.

soil, shallow emergent vegetation, and grain crops within $10 \mathrm{~km}$ were the most important variables contributing to occupancy by diving birds, dabbling ducks, and raptors, respectively. Local variables were more important than landscape variables for all guilds except geese and raptors. Wetland area, number of vegetation zones, proportion of shallow emergent vegetation, proportion of deep emergent, and grain crops influenced occupancy positively in all models in which they were included. Proportion of moist soil on site and corn in the adjacent landscape negatively influenced occupancy by diving birds and geese, respectively. Where year was included in best fitting models, it was related to occupancy negatively, likely because of the reduced survey effort in 2009. 
Table 3 Criteria of Restored Wetlands Favoring Occurrence of SpecialStatus Birds in California's Central Valley, April-July

\begin{tabular}{lccc}
\hline Species & $\begin{array}{c}\text { Years since } \\
\text { restoration }\end{array}$ & Management & Sub-basin \\
\hline American White Pelican & $<5$ & $\begin{array}{c}\text { Intermediate and } \\
\text { intensive }\end{array}$ & Sacramento \\
Loggerhead Shrike & $>5$ & Intensive & Tulare \\
Long-billed Curlew & $>5$ & Intensive & Sacramento \\
Northern Harrier & $>5$ & Intensive & Tulare \\
Nuttall's Woodpecker & $>5$ & Intensive & Sacramento \\
Song Sparrow & $<5$ & Intensive & Sacramento \\
Whimbrel & $>5$ & Intensive & Sacramento and Tulare \\
Yellow Warbler & $>5$ & Unmanaged & Sacramento \\
Yellow-billed Magpie & $<5$ & Intermediate & Sacramento \\
\hline
\end{tabular}

\section{DISCUSSION}

Wetlands provide multiple ecosystem services (Millennium Ecosystem Assessment 2005), for which restored wetlands in the Central Valley are often managed to provide only a small subset. Assessing the services restored wetlands deliver beyond those their management prescribes may help us create systems that more closely resemble their natural counterparts and are more resilient when the climate is unfavorable and resources are few.

Actively managed wetlands are used more often and support greater numbers of waterbirds than do unmanaged wetlands (Kaminski et al. 2006, O'Neal et al. 2010, Kahara et al. 2012), suggesting an important role for

Table 4 Richness and Diversity of Bird Species in Restored Wetlands of California's Central Valley, April-July, 2008-2009, by Intensity of Management, Sub-basin, and Time since Restoration

\begin{tabular}{lccc}
\hline & $n$ & $\begin{array}{c}\text { Mean species richness } \\
( \pm \text { SE, range })^{a}\end{array}$ & $\begin{array}{c}\text { Mean Shannon-Wiener } \\
\text { index }\left( \pm \text { SE, range }{ }^{a}\right)\end{array}$ \\
\hline $\begin{array}{l}\text { Intensity of management } \\
\quad \text { Unmanaged }\end{array}$ & 15 & $12.97(28.85,37.15)$ & $5.29(6.02,23.24)$ \\
$\quad \begin{array}{l}\text { Intermediate } \\
\quad \text { Intensive }\end{array}$ & 31 & $13.81(27.23,37.25)$ & $5.72(4.34,20.88)$ \\
Sub-basin & 26 & $13.02(1.20,36.83)$ & $6.01(4.18,16.50)$ \\
$\quad$ Sacramento & 21 & $13.90(1.46,37.83)$ & $6.35(0.73,23.26)$ \\
$\quad$ San Joaquin & 6 & $17.98(3.08,20.00)$ & $3.84(1.25,6.61)$ \\
$\quad$ Tulare & 15 & $9.61(1.39,16.82)$ & $4.38(0.44,5.28)$ \\
Time since restoration & & & \\
$\quad<5$ years & 42 & $11.82(1.35,37.83)$ & $4.94(0.60,20.89)$ \\
$\quad>5$ years & 30 & $15.49(1.89,37.15)$ & $6.84(0.98,23.26)$ \\
\hline
\end{tabular}

${ }^{a}$ Largest value minus smallest value. 
Table 5 Factors Influencing Probability of Detection and Occupancy of Guilds of Birds in Restored Wetlands of California's Central Valley, AprilJuly, 2008-2009

\begin{tabular}{|c|c|c|}
\hline Guild & Detection probability & Occupancy \\
\hline Wading birds & None & Number of vegetation zones \\
\hline Marsh birds & Number of surveys & $\begin{array}{l}\text { Extent of wetland, year, extent of nearby } \\
\text { cultivated cropland, frequency of } \\
\text { management, number of vegetation } \\
\text { zones }\end{array}$ \\
\hline Geese & None & Sub-basin, extent of corn nearby \\
\hline Diving birds & Number of surveys & Extent of wetland, proportion of moist soil \\
\hline Dabbling ducks & Number of surveys & $\begin{array}{l}\text { Number of vegetation zones, proportion } \\
\text { of shallow emergent vegetation }\end{array}$ \\
\hline Shorebirds & Number of surveys & $\begin{array}{l}\text { Extent of wetland, year, extent of grain } \\
\text { crops nearby, number of vegetation } \\
\text { zones }\end{array}$ \\
\hline Aerial feeders & Number of surveys & $\begin{array}{l}\text { Extent of wetland, year, proportion of } \\
\text { deep emergent vegetation }\end{array}$ \\
\hline Raptors & Number of surveys & $\begin{array}{l}\text { Extent of wetland, extent of grain crops } \\
\text { nearby }\end{array}$ \\
\hline Upland birds & None & None \\
\hline
\end{tabular}

management. However, our results suggest that management carried out in the spring and summer is less important in determining bird occupancy than are characteristics of the site's habitat and adjacent land use. Occupancy by waterbirds and upland birds was more likely to be a function of a wetland's size, vegetation composition, and diversity. Although any wetland changes seasonally with germination of food plants and flooding, unmanaged wetlands are more likely than managed wetlands to remain consistent across seasons. Surprisingly, nearly half of all unmanaged wetlands we studied held more and deeper water over the summer than did intermediate or intensively managed wetlands. Therefore, lack of management does not preclude year-round water.

Though management of water and vegetation in most restored wetlands in the Central Valley follows a prescribed regime to create optimal habitat for wintering waterfowl, the timing and duration of these practices may be adjusted to cater to spring and summer bird use. For example, lowering water levels over 2 to 3 weeks between January and March may favor abundant seed production by plants such as smartweed (Polygonum spp.; Heitmeyer et al. 1989), but this schedule is too early for migratory shorebirds, whose numbers peak in April. A drawdown in April and May would provide shorebirds more habitat during migration. Alternatively, an even later drawdown (between May and June) would greatly benefit nesting shorebirds, particularly in the San Joaquin and Tulare sub-basins where there is less habitat for them than in the Sacramento Valley (Duffy et al. 2011, Kahara et al. 2012). Partial drawdowns and a greater diversity of hydrological regimes should maximize waterbird potential, and delaying vegetation management, 
such as eradication of undesirable plants by disking, burning, shredding, or mowing, would benefit a broad spectrum of nesting birds.

Landscape covariates appeared in many of the top bird-occupancy models but were not as important as characteristics of the site's habitat, as found by Valente et al. (2011). Bird-habitat relationships were consistent with previous studies, including relationships with extent of wetland (VanRees-Siewert and Dinsmore 1996, Naugle et al. 2001, Webb et al. 2010) and of shallow emergent vegetation (Kaminski and Prince 1984, Murkin et al. 1992, Webb et al. 2010). After extent of wetland, the presence of complex vegetation mosaics was the second most important factor contributing to occupancy. The guilds most likely to be affected by vegetation diversity were wading birds, marsh birds, dabbling ducks, and shorebirds. The gradient of vegetation zones observed at many of the restored sites creates structural heterogeneity and diverse food and habitat resources that may explain the diversity of bird species we observed under all management regimes. Vegetation diversity may be achieved through variation in topography in larger ( $>40$ ha) wetlands or by maintaining multiple smaller ( $<4 \mathrm{ha}$ ) management units at different successional stages (Fredrickson and Taylor 1982).

Contrary to our expectations, grain crops in the adjacent landscape enhanced bird occupancy of wetlands, but this may have been a consequence of the timing of our study. In the fall and winter, flooded grain crops attract both wetland and upland species (Miller et al. 1989, Elphick and Oring 1998, Elphick 2000, Czech and Parsons 2002, Ma et al. 2010, Fleskes et al. 2012), possibly drawing them away from restored wetlands. Over the spring and summer, however, disturbance from increased agricultural activity may have the opposite effect and drive birds onto restored wetlands, elevating their importance as refugia during this period.

In the Central Valley, heavy dependence on irrigation for moist-soil management means that habitat availability for birds is a function not only of the weather but also of individual landowners' water rights and state regulations. Wetland managers in the drier southern Central Valley face greater challenges obtaining water than those in the north, which receives up to four times more rainfall. In the Tulare sub-basin, wetland managers have historically depended on groundwater, which is rapidly diminishing, becoming increasingly expensive, and contaminated (Hartmann and Goldstein 1994). The more frequent multi-year droughts forecast for the future may force the adoption of alternatives to intensive moist-soil management. Nevertheless, as we found, lack of management does not necessarily negate the value of restored wetlands, even if the effect on wintering waterfowl is severe. Creation of larger tracts with complex vegetation mosaics may allow unmanaged wetlands to continue to support a diverse avifauna in the spring and summer.

\section{ACKNOWLEDGMENTS}

We greatly appreciate the generous cooperation of all participating landowners and land managers. The staff of the Colusa, Kern, Pixley, Sacramento, and San Joaquin national wildlife refuges provided access and assistance. For their assistance with habitat and bird surveys we also thank Beth Werner, Shannon Chapin, Mary Burke, and Bryan Atkinson. J. Groves and C. Hickey provided valuable guidance. The manuscript was improved by the thoughtful comments and edits of Ron LeValley, 


\section{BIRD USE OF RESTORED WETLANDS IN THE CENTRAL VALLEY}

Philip Unitt, and an anonymous reviewer. Funding for this research was provided by the NRCS Conservation Effects Assessment Project-Wetlands.

\section{LITERATURE CITED}

Ackerman, J. T., Takekawa, J. Y., Orthemeyer, D. L., Fleskes, J. P., Yee J. L., and Kruse K. L. 2006. Spatial use by Greater White-fronted Geese relative to a decade of habitat change in California's Central Valley. J. Wildlife Mgmt. 70:965-976; doi 10.2193/0022-541X(2006)70[965:SUBWGW]2.0.CO;2.

Beedy, E. C., and Hamilton W. J., III. 1999. Tricolored Blackbird (Agelaius tricolor), in The Birds of North America (A. Poole and F. Gill, eds.), no. 423. Birds N Am., Philadelphia; doi 10.2173/bna.423.

Burnham, K. P., and Anderson, D. R. 2002. Model Selection and Multimodel Inference: A Practical Information-Theoretical Approach, 2nd ed. Springer-Verlag, New York.

Carter, J. L., and Resh, V. H. 2005. Pacific Coast rivers of the conterminous United States, in Rivers of North America. (A. C. Benke and C. E. Cushing, eds.), pp. 547-557. Elsevier, Amsterdam; doi 10.1016/B978-012088253-3/50015-8.

Central Valley Joint Venture. 2006. Central Valley Joint Venture implementation plan-conserving bird habitat. U.S. Fish and Wildlife Service, Sacramento.

Czech, H. A., and Parsons K.C. 2002. Agricultural wetlands and waterbirds: A review. Waterbirds 25:56-65.

Dahl, T.E. 1990. Wetland losses in the United States 1780's to 1980's. U.S. Fish and Wildlife Service, Washington, D.C.

Duffy, W.G., Garone, P., Grewell, B. J., Kahara, S., Fleskes, J., Helm, B., Moyle, P., Records, R., and Silveira, J. 2016. Wetlands, in Ecosystems of California: A Source Book (E. Zavaleta and H. Mooney, eds.), pp. 669-692. Univ. of Calif. Press, Berkeley.

Duffy, W. G., Kahara S. N., and Records R. M. 2011. Conservation Effects Assessment Project-Wetlands assessment in California's Central Valley and Upper Klamath River Basin. U.S. Geol. Survey Open-File Rep. 2011-1290; http://pubs.usgs. gov/of/2011/1290 (8 Aug 2012).

Elphick, C. S. 2000. Functional equivalency between rice fields and seminatural wetland habitats. Cons. Biol. 14:181-191; doi 10.1046/j.1523-1739.2000.98314.x.

Elphick, C. S., and Oring L. W. 1998. Winter management of Californian rice fields for waterbirds. J. Appl. Ecol. 35:95-108; doi 10.1046/j.1365-2664.1998.00274.x.

Fleskes, J. P., Skalos D. A., and Farinha M. A. 2012. Bird use of fields treated postharvest with two types of flooding in Tulare basin, California. J. Fish and Wildlife Mgmt. 3:164-174; doi 10.3996/092011-JFWM-056.

Fredrickson, L. H., and Taylor, T. S. 1982. Management of seasonally flooded impoundments for wildlife. U.S. Fish and Wildlife Service Resource Publ. 148.

Garone, P. 2011. The fall and rise of wetlands of California's Great Central Valley. Univ. of Calif. Press, Berkeley.

Gilmer, D. S., Miller M. R., Bauer R. D., and LeDonne J. R. 1982. California's Central Valley wintering waterfowl: Concerns and challenges. Transactions of the North American Wildlife and Natural Resources Conference 47:441- 452.

Hartmann, J. R., and Goldstein J. H. 1994. The impact of federal programs on wetlands, vol. 2. U.S. Dept. of Interior, Office of Policy Analysis, Washington, D.C.

Heitmeyer, M. E., Connelly, D. P., and Pederson, R. L. 1989. The Central, Imperial, and Coachella valleys of California, in Habitat Management for Migrating and Wintering Waterfowl in North America (L. M. Smith, R. L. Pederson, and R. M. Kaminski, eds.), pp. 475-505. Texas Tech Univ. Press, Lubbock.

Hickey, C., Wood, J., Stenzel, L., DiGaudio, R., Page, G., Culp, L., Tonra, C., Kreitinger, K., and Geupel, G. 2008. Bird monitoring on private lands: Measuring bird response to easement, restoration, enhancement, and incentive programs in the Central Valley, 2004-2006; PRBO Cons. Sci., Petaluma, CA.

Kahara, S. N., Duffy, W. G., DiGaudio, R., and Records, R. 2012. Climate, manage- 
ment and habitat associations of bird fauna in restored wetlands of California's Central Valley, USA. Diversity 4:396-418; doi 10.3390/d4040396.

Kaminski, M. R., Baldasarre, G. A., and Pearse, A. T. 2006. Waterbird responses to hydrological management of Wetlands Reserve Program habitats in New York. Special section: Farm bill contributions to wildlife conservation. Wildlife Soc. Bull. 34:921-926; doi 10.2193/0091-7648(2006)34[921:WRTHMO]2.0.CO;2.

Kaminski, M. R., and Prince, H. H. 1984. Dabbling duck-habitat associations during spring in Delta marsh, Manitoba. J. Wildlife Mgmt. 48:37-50; doi 10.2307/3808451.

Katibah, E. F. 1984. A brief history of riparian forests in the Central Valley of California. in California Riparian Systems: Ecology, Conservation and Management (R. E. Warner and K. M. Hendrix, eds.), pp. 23-29. Univ. of Calif. Press, Berkeley.

Ma, Z., Yinting, C., Li, B., and Chen, J. 2010. Managing wetland habitats for waterbirds: An international perspective. Wetlands 30:15-27; doi 10.1007/ s13157-009-0001-6.

MacKenzie, D. I., Nichols, J. D., Lachman, G. B., Droege, S., Royle, J. A., and Langtimm, C. A. 2002. Estimating site occupancy rates when detection probabilities are less than one. Ecology 83:2248-2255; doi 10.1890/0012-9658(2002) 083[2248:ESORWD]2.0.CO;2.

Millennium Ecosystem Assessment. 2005. Ecosystems and Human Well-being: Wetlands and Water Synthesis. World Resources Institute, Washington, D.C.

Miller, M. R., Sharp, D. E., Gilmer, D. S., and Mulvaney, W. R. 1989. Rice available to waterfowl in harvested fields in the Sacramento Valley, California. Calif. Fish and Game 75:113-123.

Murkin, E. J., Murkin, H. R., and Titman, R. D. 1992. Nektonic invertebrate abundance and distribution at the emergent vegetation-open water interface in the Delta Marsh, Manitoba, Canada. Wetlands 12:45-52; doi 10.1007/BF03160543.

Naugle, D. E., Johnson, R. R., Estey, M. E., and Higgins, K.F. 2001. A landscape approach to conserving wetland bird habitat in the prairie pothole region of eastern South Dakota. Wetlands 21:1-17; doi 10.1672/0277-5212(2001)021[0001:ALA TCW]2.0.CO;2.

O'Neal, B. J., Heske, E. J., and Stafford, J. D. 2010. Waterbird response to wetlands restored through the Conservation Reserve Enhancement Program. J. Wildlife Mgmt. 72:654-664; doi 10.2193/2007-165.

Ralph, C. J., Geupel, G. R., Pyle, P., Martin, T. E., and DeSante, D. E. 1993. Handbook of field methods for monitoring landbirds. U.S. Forest Service, Pacific Southwest Research Station, Albany, CA.

Schoenherr, A. A. 1992. A Natural History of California. Univ. of Calif. Press, Berkeley.

Sterling, J., and Buttner, P. 2011. Wildlife known to use California ricelands. Calif. Rice Commission, Sacramento.

Valente, J. J., King, S. L., and Wilson, R. R. 2011. Distribution and habitat associations of breeding secretive marsh birds in Louisiana's Mississippi Alluvial Valley. Wetlands 31:1-10; doi 10.1007/s13157-010-0138-3.

Van der Valk, A. G., and Davis, C. B. 1978. The role of seed banks in the vegetation dynamics of prairie glacial marshes. Ecology 59:322-335; doi 10.2307/1936377.

VanRees-Siewert, K. L., and Dinsmore, J. J. 1996. Influence of wetland age on bird use of restored wetlands in lowa. Wetlands 16:577-582; doi 10.1007/ BF03161348.

Webb, E. B., Smith, L. M., Vrtiska, M. P., and Lagrange, T. G. 2010. Effects of local and landscape variables on wetland bird habitat use during migration through the Rainwater Basin. J. Wildlife Mgmt. 74:109-119; doi 10.2193/2008-577.

Zuckerberg, B., and Vickery, P. D. 2006. Effects of mowing and burning on shrubland and grassland birds on Nantucket Island, Massachusetts. Wilson J. Ornithol. 118:353-363; doi 10.1676/05-065.1. 